\title{
The Evolution of A $\beta$ Peptide Burden in the APP23 Transgenic Mice: Implications for $A \beta$ Deposition in Alzheimer Disease
}

\author{
Yu-Min Kuo, ${ }^{1}$ Thomas G. Beach, ${ }^{2}$ Lucia I. Sue, ${ }^{2}$ Sarah Scott, ${ }^{2}$ Kathryn J. Layne, ${ }^{2}$ Tyler A. Kokjohn, ${ }^{3}$ \\ Walter M. Kalback, ${ }^{1}$ Dean C. Luehrs, ${ }^{1}$ Tatiana A. Vishnivetskaya, ${ }^{1}$ Dorothee Abramowski, ${ }^{4}$ Christine \\ Sturchler-Pierrat, ${ }^{4}$ Matthias Staufenbiel, ${ }^{4}$ Roy O. Weller, ${ }^{5}$ and Alex E. Roher ${ }^{1}$
${ }^{1}$ The Longtine Center for Molecular Biology and Genetics, Sun Health Research Institute, Sun City, Arizona
${ }^{2}$ The Civin Laboratory of Neuropathology, Sun Health Research Institute, Sun City, Arizona
${ }^{3}$ Department of Microbiology, Midwestern University, Glendale, Arizona
${ }^{4}$ Novartis Pharma, Inc., Basel, Switzerland
${ }^{5}$ Department of Pathology, University of Southampton School of Medicine, Southampton General Hospital, Southampton, United Kingdom

Accepted July 7, 2001

\begin{abstract}
Background: High levels of $\mathrm{A} \beta$ in the cerebral cortex distinguish demented Alzheimer's disease (AD) from nondemented elderly individuals, suggesting that decreased amyloid-beta $(\mathrm{A} \beta)$ peptide clearance from the brain is a key precipitating factor in $\mathrm{AD}$.

Materials and Methods: The levels of $\mathrm{A} \beta$ in brain and plasma as well as apolipoprotein $\mathrm{E}$ (ApoE) in brain were investigated by enzyme-linked immunosorbent assay (ELISA) and Western blotting at various times during the life span of the APP23 transgenic (Tg) and control mice. Histochemistry and immunocytochemistry were used to assess the morphologic characteristics of the brain parenchymal and cerebrovascular amyloid deposits and the intracellular amyloid precursor protein (APP) deposits in the APP23 Tg mice.

Results: No significant differences were found in the plasma levels of A $\beta$ between the APP23 Tg and control mice from 2-20 months of age. In contrast, soluble $\mathrm{A} \beta$ levels in the brain were continually elevated, increasing 4 -fold at 2 months and 33-fold in the APP23 Tg mice at 20 months of age when compared to the control mice. Soluble $\mathrm{A} \beta 42$
\end{abstract}

was about $60 \%$ higher than A $\beta 40$. In the APP23 Tg mice, insoluble $\mathrm{A} \beta 40$ remained at basal levels in the brain until 9 months and then rose to $680 \mu \mathrm{g} / \mathrm{g}$ cortex by 20 months. Insoluble $\mathrm{A} \beta 40$ was negligible in non-Tg mice at all ages. Insoluble A $\beta 42$ in APP23 Tg mice rose to $60 \mu \mathrm{g} / \mathrm{g}$ cortex at 20 months, representing 24 times the control A $\beta 42$ levels. Elevated levels of ApoE in the brain were observed in the APP23 Tg mice at 2 months of age, becoming substantially higher by 20 months. ApoE colocalized with $\mathrm{A} \beta$ in the plaques. Beta-amyloid precursor protein ( $\beta$ APP) deposits were detected within the neuronal cytoplasm from 4 months of age onward. Amyloid angiopathy in the APP23 Tg mice increased markedly with age, being by far more severe than in the Tg2576 mice.

Conclusions: We suggest that the APP23 Tg mouse may develop an earlier blockage in $\mathrm{A} \beta$ clearance than the Tg2576 mice, resulting in a more severe accumulation of $\mathrm{A} \beta$ in the perivascular drainage pathways and in the brain. Both Tg mice reflect decreased $\mathrm{A} \beta$ elimination and as models for the amyloid cascade they are useful to study AD pathophysiology and therapy.

\section{Introduction}

Alzheimer's disease (AD) has a multifactorial pathogenesis in which one of the major features is the deposition of amyloid-beta $(\mathrm{A} \beta)$ peptides as plaques in brain parenchyma and in vessel walls as cerebral amyloid angiopathy (CAA). Despite the prominence of insoluble deposits of $\mathrm{A} \beta$ in the $\mathrm{AD}$ brains, recent observations suggest that these brains can be distinguished from those of nondemented elderly, not only by the amount of insoluble $\mathrm{A} \beta$ in plaques in the

Address correspondence and reprint requests to: Dr. Alex E. Roher, The Longtine Center for Molecular Biology and Genetics, Sun Health Research Institute, 10515 West Santa Fe Drive, Sun City, Arizona 85351. Phone: (623) 876-5465; fax: (623) 876-5698; e-mail: alex.roher@sunhealth.org brain but also by the high levels of soluble $\mathrm{A} \beta(1,2)$. This suggests that failure of soluble $A \beta$ to clear from the extracellular space of the cortex may play a major role in the induction of dementia in $\mathrm{AD}$. The questions therefore arising are: how does $\mathrm{A} \beta$ normally drain from the brain, how is this drainage impeded, and how can drainage of $\mathrm{A} \beta$ be improved?

Tracer studies and physiologic experiments in rodents have shown that drainage of interstitial fluid and proteins from the extracellular space of the brain depends on (1) the size and charge of the molecules, (2) the dimensions of the extracellular space of the cortex, and (3) the presence of flow channels around capillaries and arteries (3-6). The pattern of distribution of a number of different amyloids such as $\mathrm{A} \beta$ (7), cystatin (8), PrP (9), and ABri $(10,11)$ in their 
respective cerebral amyloid angiopathies suggests that amyloid peptides are deposited in perivascular drainage pathways, both within the cortex and in the leptomeninges (12). Defining the biochemical factors and physiologic influences that govern drainage of all these amyloid peptides from the human brain will offer therapeutic opportunities for the reduction in amyloid load in the brain and thus possibly amelioration of the clinical features of AD and other dementias.

The development of beta-amyloid precursor protein (APP) transgenic (Tg) mice carrying mutations that enhance the production of the $\mathrm{A} \beta$ peptides has opened new avenues for testing the hypothesis that failure of perivascular drainage of $\mathrm{A} \beta$ is a major event in the pathogenesis of AD. In this dementia, the amount of insoluble $A \beta n-40$ and $A \beta n-42$ accumulating in the brain parenchyma and cerebrovascular walls appears to be intimately correlated with the apolipoprotein E (ApoE) genotype. In the brain, ApoE plays a major role in the transport of cholesterol and triglycerides, and in the transport and clearance of $\mathrm{A} \beta$ peptides, and is synthesized by astroglial and microglial cells. In humans there are three allelic forms of ApoE recognized as $\varepsilon 2, \varepsilon 3$, and $\varepsilon 4$, which code for three ApoE polypeptides: ApoE2, ApoE3, and ApoE4. There is a definitive association between the number of copies an individual has of the ApoE4 form and the risk of developing early-onset $A D$ as well as between ApoE4 and the CAA in AD. Those carrying the ApoE $\varepsilon 4 / \varepsilon 4$ genotype have an overwhelming amount of amyloid deposited in the brain parenchyma and in cortical and leptomeningeal vessel walls.

The APP Tg mice also provide an opportunity for tracking amyloid deposition and drainage. Thus, throughout the life span of these rodents, the level of water-soluble and water-insoluble $\mathrm{A} \beta$ peptides and ApoE can be measured in the brain and correlated with levels of soluble $\mathrm{A} \beta$ in the plasma. From a chemical viewpoint, the $\mathrm{A} \beta$ peptides can be structurally analyzed and equated with the type of amyloid deposits observed morphologically. Furthermore, the differences between strains of Tg mice can be determined, thus offering different facets of the spectrum of amyloid deposition and drainage. Most importantly, however, the Tg animal models would be ideal for assessing the efficacy of drugs or antibodies destined to increase clearance of $\mathrm{A} \beta$, reduce the amyloid burden, and enhance cognitive ability.

The present study compares levels of $\mathrm{A} \beta$ in blood and brain throughout the life span of APP23 Tg mice. In this strain, the $\beta$ APP gene expression is driven by the neuronal Thy-1 promoter. Amyloid deposition is first visible microscopically in the brain parenchyma and in arterial walls as CAA at about 7-9 months of age (13). A $\beta$ levels in the brain and plasma are compared between APP23 Tg and control mice from 2-20 months of age. Because the age of onset of sporadic AD and the metabolism of
$\mathrm{A} \beta$ appear to be intimately associated with ApoE (14), we also determined the levels of ApoE in the mouse brain tissue. Finally, the pattern of $\mathrm{A} \beta$ accumulation in the brain in APP23 Tg mice is compared to that of another strain of APP Tg mouse, the Tg2576, that we characterized previously (15). We hypothesize that a progressive failure in the clearance of $\mathrm{A} \beta$ from the brain to the blood in the $\beta$ APP $23 \mathrm{Tg}$ mice results in the characteristic accumulation pattern of both soluble and insoluble $\mathrm{A} \beta$ in the brains of these animals.

\section{Materials and Methods}

Animals and Tissues

The levels of $A \beta 40$ and $A \beta 42$ were estimated in the blood and in the brains of the APP23 Tg mice and in non-Tg control mice. In the brain, the $A \beta$ peptides were quantified in the water-soluble and water-insoluble tissue fractions. A total of 72 mice were used in these experiments: 36 were Tg for the human $\beta \mathrm{APP}_{751}$ carrying the Swedish mutations (K670N and M671L) under the neuronal murine Thy-1 promoter fragment, and 36 were wild-type littermates that acted as controls. At 2, 4, 9, 12, 14, and 20 months of age, six Tg mice and six controls were selected with equal numbers of male and female mice. All Tg mice used in this study were hemizygous.

\section{Blood}

Approximately $1 \mathrm{ml}$ of blood was obtained by cardiac puncture and drained into a $1-\mathrm{ml}$ syringe primed with $25 \mu \mathrm{l}$ of ethylenediaminetetraacetic acid (EDTA) as anticoagulant. The plasma was separated from the formed elements by centrifugation and stored at $-80^{\circ} \mathrm{C}$ until used. Mouse brains were removed immediately post mortem; the left cerebral hemispheres were rapidly frozen in liquid nitrogen and stored at $-80^{\circ} \mathrm{C}$ and the right hemispheres were fixed in $4 \%$ buffered paraformaldehyde.

\section{Isolation and Quantification of $A \beta$ Peptides}

Blood One hundred microliters of the rodent plasma was diluted with $400 \mu \mathrm{l}$ of $98 \%$ formic acid (Fluka Chemie AG, Buchs, Switzerland; glass distilled in our laboratory) and loaded onto a sizeexclusion Superose 12-column equilibrated with $80 \%$ glass distilled formic acid (GDFA). Plasma fractionation was carried out on a Fast Performance Liquid Chromatography apparatus (FPLC, Pharmacia Biotech, Uppsala, Sweden) at a flow rate of $15 \mathrm{ml}$ per hr at room temperature (RT) and monitored at $280 \mathrm{~nm}$. Fractions containing the 3- to 8-kDa peptides were collected in polypropylene tubes, pooled, and, after the addition of $5 \mu \mathrm{l}$ of $2 \%$ betaine, the acid was eliminated by vacuum centrifugation. The dried specimens were dissolved in $50 \mu \mathrm{l}$ of $80 \%$ GDFA, then diluted with $250 \mu \mathrm{l}$ of $10 \mathrm{X}$ TTBS $(0.5 \mathrm{M}$ Tris-HCl, pH 8.0, $1.37 \mathrm{M} \mathrm{NaCl}, 27 \mathrm{mM} \mathrm{KCl}, 0.5 \%$ 
Tween 20). Volumes were then adjusted to $1 \mathrm{ml}$ with distilled water (DW), the $\mathrm{pH}$ adjusted to 7.4 with $10 \mathrm{~N} \mathrm{NaOH}$ using a pH meter equipped with a microelectrode and each specimen's volume adjusted to $2.5 \mathrm{ml}$ with DW. Samples were immediately submitted to $\mathrm{A} \beta$ immunoassay: $50 \mu \mathrm{l}$ of the capture antibody were plated either with the R163 antibody raised against $A \beta$ residues $34-40$ or with the $R 165$ antibody raised against $\mathrm{A} \beta$ residues $36-42$, at concentrations of $10 \mu \mathrm{g} / \mathrm{ml}$ in $10 \mathrm{mM}$ sodium carbonate, $\mathrm{pH}$ 9.6. After the addition of $100 \mu \mathrm{l}$ of blocking solution ( $1 \%$ bovine serum albumin in TTBS), the plates were incubated for $1 \mathrm{hr}$ at RT. Either $100 \mu \mathrm{l}$ of the test specimens or of the $A \beta 40$ or $A \beta 42$ standards was added in triplicate and the plates incubated for $2 \mathrm{hr}$ at RT on a rocking apparatus. Unbound materials were removed by 4 TTBS automatic washes (Tecan, Salzburg, Austria). After addition of $50 \mu \mathrm{l}$ of the reporting antibody (4G8, raised against residues 17-24 of $\mathrm{A} \beta$ ) labeled with europium according to the manufacturer's specifications (Wallac Inc., Gaithersburg, MD, USA), the specimens were incubated for $1 \mathrm{hr}$ at RT and washed four times with TTBS and three times with DW. Following addition of $50 \mu \mathrm{l}$ of the Enhancement Solution (Wallac Inc.), the plates were read in a fluorimeter (Wallac Inc.) at an excitation of $340 \mathrm{~nm}$ and emission of $615 \mathrm{~nm}$. The concentrations of $A \beta$ in the samples were calculated using the standard curves generated by each plate (range $25-1000 \mathrm{pg} / \mathrm{ml}$ ) as a frame of reference and the final values adjusted to $\mathrm{ng} / \mathrm{ml}$ considering the experimental dilution factors.

Brain The amounts of water-soluble and waterinsoluble $\mathrm{A} \beta$ peptides were related to the amount of brain tissue (in $\mathrm{mg}$ ) in the sample. Left cerebral hemispheres from each mouse were minced and thoroughly disrupted with a Dounce homogenizer in $4 \mathrm{ml}$ of $50 \mathrm{mM}$ Tris $\mathrm{HCl}$, pH 7.4 buffer containing a mixture of protease inhibitors (1 mM EDTA, $500 \mu \mathrm{g} / \mathrm{l}$ leupeptin, $700 \mu \mathrm{g} / \mathrm{l}$ pepstatin, $350 \mathrm{mg} / \mathrm{l}$ phenylmethylsulfonyl fluoride, $100 \mathrm{mg} / \mathrm{l} o$-phenanthroline, and $100 \mathrm{mg} / \mathrm{l}$ benzamidine). The specimens were centrifuged at $100,000 \times \mathrm{g}$ in a Sorvall $\mathrm{AH}-650$ rotor at $4^{\circ} \mathrm{C}$ for $1 \mathrm{hr}$. One hundred microliters of the supernatant was applied to the microtiter plates for europium immunoassay of water-soluble $\mathrm{A} \beta$ peptides. The insoluble pellets were homogenized in $1 \mathrm{ml}$ of $2 \%$ SDS. Five hundred microliters of the homogenate was mixed with $2 \mathrm{ml}$ of $90 \%$ GDFA. Fifty microliters of the acid lysate was neutralized as mentioned for the plasma samples with the exception that the final volume was brought up to $5 \mathrm{ml}$ instead of $2.5 \mathrm{ml}$ and submitted to europium immunoassay. The final yields of soluble and insoluble $\mathrm{A} \beta$ were adjusted to $\mu \mathrm{g}$ per $\mathrm{g}$ of cerebral cortex.

\section{Protein Quantification and Western Blotting}

Protein determinations were performed on the aqueous supernatants and water-insoluble pellets of brain tissue. The pellets were homogenized in $1 \mathrm{ml}$ of $2 \%$ SDS in $20 \mathrm{mM}$ Tris $\mathrm{HCl}, \mathrm{pH}$ 8.0, and diluted 500 times prior to application to the microtiter plates. The protein values were determined using Micro BCA Protein Assay reagent kit (Pierce, Rockford, IL, USA).

Western blotting was used to determine the levels of ApoE in the mouse brains. For this purpose we used a goat anti-rat polyclonal antibody (see below). This antibody was raised against rat ApoE purified by the method of Holmquist and Carlson (16), its purity assessed by SDS-PAGE (17), and its specificity confirmed by two-dimensional crossed immunoelectrophoresis (18). The Western blots were developed with the Supersignal Chemiluminescent Subtrate (Pierce) and the relative intensity of the bands measured on a scanning ChemiImager (Alpha Innotech Corp., San Leandro, CA, USA).

Histochemical and Immunohistochemical Analyses The right hemispheres from the Tg and non-Tg mice were fixed for $48 \mathrm{hr}$ in $4 \%$ paraformaldehyde in $0.1 \mathrm{M}$ phosphate buffer, $\mathrm{pH}$ 7.4, the tissue dehydrated with alcohols and xylene, and embedded in paraffin wax. Parasagittal 5- $\mu \mathrm{m}$ thick sections of whole-hemisphere sections were stained with modified Cambell-Switzer, hematoxylin and eosin, thioflavine $S$, and by immunohistochemistry (19) for A $\beta, \beta$ APP, and ApoE. The primary antibodies used for $\mathrm{A} \beta$ were $6 \mathrm{E} 10$ (Senetec, Maryland Heights, MO, USA) against the $\mathrm{A} \beta$ amino acid sequence 1-17, and R163 and R165 against the $\mathrm{C}$-terminal portions of the $\mathrm{A} \beta$ peptide ending at amino acids 40 and 42 (20), respectively (all three were used at a dilution of 1:1000). Frozen sections $(40-\mu \mathrm{m}$ thick) from an additional set of two APP23 Tg animals and two non-Tg animals for each age point in this study were used for immunohistochemical staining for ApoE (anti-rat ApoE, kindly provided by Dr. C. Bisgaier, Esperion Therapeutics, Inc. and by Dr. P. Dolphin, Dalhousie University) at a dilution of 1:100, and for heparan sulfate proteoglycan (Chemicon, Temecula, CA, USA). For $\beta$ APP, the 22C11 antibody (Boehringer-Mannheim, Indianapolis, IN, USA) against the N-terminus and the R37 antibody (21) against the C-terminus were used at dilutions of 1:50 and 1:5000, respectively. Sections stained for $\mathrm{A} \beta$ were pretreated for 5 min with $90 \%$ formic acid while those stained for $\beta$ APP with the $22 \mathrm{Cl} 1$ antibody were pretreated for $1 \mathrm{~min}$. Sections stained for ApoE or $\beta$ APP with the R37 antibody were first boiled for $10 \mathrm{~min}$ in $0.1 \mathrm{M}$ sodium citrate buffer, pH 7.4. Secondary antibodies and avidinbiotin peroxidase complex were obtained from Vector (Burlingame, CA, USA). 3,3'-diaminobenzidine (Sigma, St. Louis, MO, USA) with $1 \%$ nickel ammonium sulfate was used as the chromogen. Some sections were counterstained with neutral red. Stained sections were viewed with bright-field light microscopy (immunoperoxidase stains) or fluorescence microscopy and confocal scanning laser microscopy (thioflavine S-stained sections). 


\section{Preparation of Whole-Mounts of Cerebral Vessels}

The cerebrums from 20-month-old APP23 Tg mice $(n=4)$, and $\operatorname{Tg} 2576$ mice $(n=4)$, were each sectioned to separate the hemispheres and coronally cut into two slices. The brain tissue was lysed with two changes of $50 \mathrm{ml}$ each of $2 \%$ SDS, 2 mM EDTA, $50 \mathrm{mM}$ Tris- $\mathrm{HCl}, \mathrm{pH} 7.4$. The tissue was very gently stirred with a magnetic bar for a period of $36 \mathrm{hr}$, after which the vascular tufts were recovered by filtration through a $40-\mu \mathrm{m}$ nylon mesh fitted at the end of a $2.5 \times 10 \mathrm{~cm}$ Plexiglass cylinder. The nylon mesh was immediately shaken into $50 \mathrm{ml}$ of DW and the vessels recovered by centrifugation at $1500 \times \mathrm{G}$ for $15 \mathrm{~min}$ and washed once more with $50 \mathrm{ml}$ of DW. The resulting SDS-insoluble vascular extracellular matrix and basal lamina with the attached amyloid were spread out on a microscope slide, air dried at $60^{\circ} \mathrm{C}$ for $3 \mathrm{hr}$, fixed with absolute ethanol for $30 \mathrm{~min}$, and rinsed with DW. The specimens were stained with $0.2 \mu \mathrm{m}$ filtered $1 \%$ aqueous thioflavine $S$ for 10 min, rinsed with $70 \%$ ethanol to remove unbound stain, and mounted under glass cover slips with a gel medium.

\section{Results}

\section{A $\beta$ Levels in $\mathrm{Tg}$ Mouse Plasma}

There was an initial elevation of the plasma levels of $\mathrm{A} \beta 40$ and $\mathrm{A} \beta 42$ from 2-9 months of age in the APP23 Tg mice (Fig. 1AB). By 14 months, levels of $\mathrm{A} \beta$ had fallen, followed by a more moderate decrease by 20 months. A similar pattern was observed in the non-Tg mouse population, with no statistically significant differences between the $\mathrm{Tg}$ and non-Tg mice at any age for both $\mathrm{A} \beta 40$ and $\mathrm{A} \beta 42$ (Fig. 1C). At 9 months of age, the average values for $\mathrm{A} \beta 40$ and $\mathrm{A} \beta 42$ in the $\mathrm{Tg}$ mice were $13 \mathrm{ng} / \mathrm{ml}$ and $19 \mathrm{ng} / \mathrm{ml}$, respectively, which were close to the values for the non-Tg mice: $8 \mathrm{ng} / \mathrm{ml}$ and $16 \mathrm{ng} / \mathrm{ml}$, respectively. By 20 months of age, the plasma levels of $\mathrm{A} \beta 40$ and $\mathrm{A} \beta 42$ in the Tg mice decreased to an average of $4 \mathrm{ng} / \mathrm{ml}$ and $3.8 \mathrm{ng} / \mathrm{ml}$, respectively. In the non-Tg mice, these values were lower: $1 \mathrm{ng} / \mathrm{ml}$ and $0.4 \mathrm{ng} / \mathrm{ml}$, respectively (Fig. $\mathrm{AAB}$ ). However, the differences between $\mathrm{A} \beta 40$ levels in $\mathrm{Tg}$ and non- $\mathrm{Tg}$ mice at 14 and 20 months were not significant ( $p=0.051$ and $p=0.113$, respectively).

\section{$A \beta$ Levels in APP23 $\mathrm{Tg}$ Mouse Brains}

The water-soluble fractions of $A \beta 40$ and $A \beta 42$ peptides in APP23 Tg mouse brain were substantially and constantly elevated at all ages when compared to the levels in non-Tg mice (Fig. 2AB). Throughout the life span of the Tg mice, the average levels of the $A \beta 42$ were higher than those of the $\mathrm{A} \beta 40(34.4 \mu \mathrm{g} / \mathrm{g}$ of cortex versus $21.6 \mu \mathrm{g} / \mathrm{g})$. In contrast, the average values for the rodent endogenous $\mathrm{A} \beta 40$ and $\mathrm{A} \beta 42$ were similar in the non-Tg mice $(3.9 \mu \mathrm{g} / \mathrm{g}$ and $4.1 \mu \mathrm{g} / \mathrm{g}$, respectively). At 2 months of age, the mean value for the total soluble $\mathrm{A} \beta$ in the brains of APP23 Tg mice was
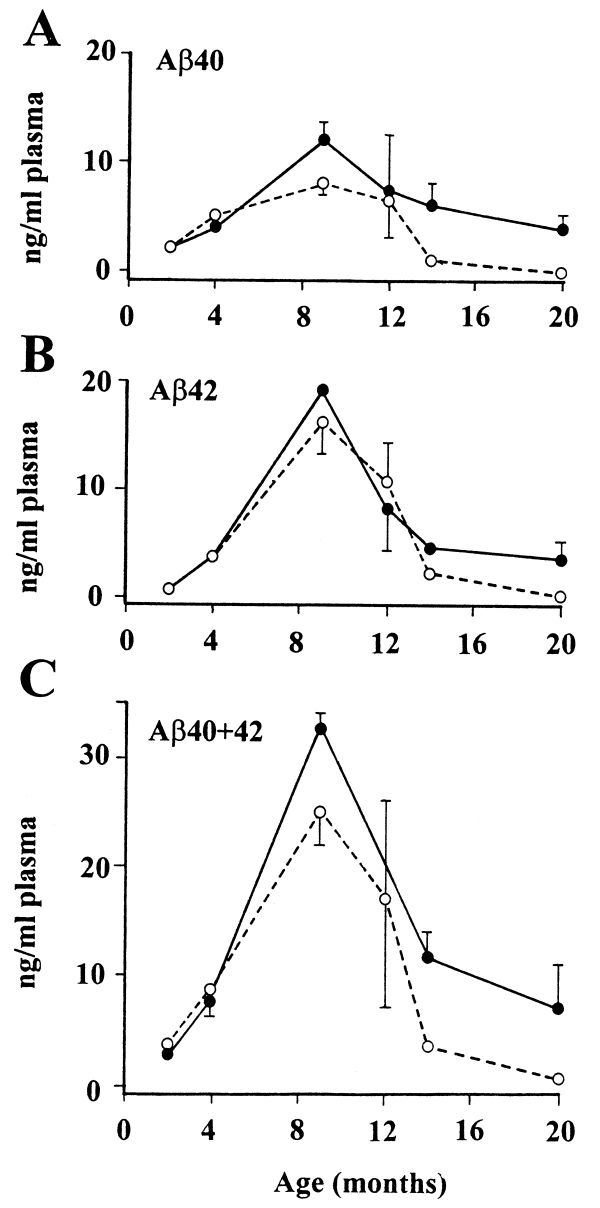

Fig. 1. The levels of $A \beta$ in the plasma of the APP23 $\mathrm{Tg}$ mice and control littermates. The measurements of these peptides were made in the 3- to 8-kDa FPLC formic acidseparated fractions at 2, 4, 9, 12, 14, and 20 months of age. Solid and broken lines correspond to the Tg mice and control mice, respectively. (A) $\mathrm{A} \beta 40$. (B) $\mathrm{A} \beta 42$. (C) the sum of $\mathrm{A} \beta 40$ and $A \beta 42$. There were no significant differences between the $\mathrm{Tg}$ and non-Tg mice.

already four times greater than in the non-Tg mice. At 20 months of age, this difference was far more pronounced, amounting to 33 times more total $\mathrm{A} \beta$ in the APP23 Tg mouse brains than in the non- $\mathrm{Tg}$ mice (Fig. 2C). The relatively high values of total soluble $\mathrm{A} \beta$ at 2 months of age in the non- $\mathrm{Tg}$ mice may result from the higher values of endogenous $\beta$ APP normally observed during fetal development.

The water-insoluble fractions of $A \beta 40$ remained at a basal level during the first 9 months after birth in the brains of the APP23 Tg mice. This was followed by a moderate increase until 14 months of age and then a sharp elevation, to $680 \mu \mathrm{g} / \mathrm{g}$ of cortex, by 20 months (Fig. 3A). As expected, the levels of endogenous insoluble $A \beta 40$ remained negligible throughout the life span of the non-Tg mice (Fig. 3A). The levels of the water-insoluble $A \beta 42$ in the APP23 Tg mice remained at a basal endogenous level until the age of 14 months but then increased 

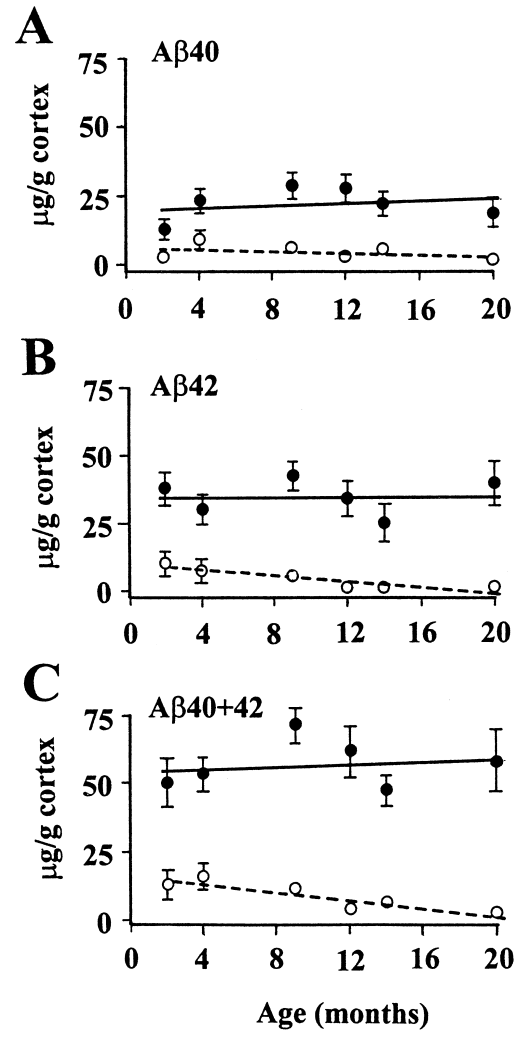

Fig. 2. The levels of water-soluble $A \beta$ in APP23 Tg mice and control littermate brains. The values were quantified by europium immunoassay (EuIA) at the same ages as in Figure 1. Solid lines, Tg mice; broken lines, control mice. (A) A $\beta 40$. (B) $\mathrm{A} \beta 42$. (C) The Summation of $\mathrm{A} \beta 40$ and $\mathrm{A} \beta 42$. Notice the high levels of soluble $\mathrm{A} \beta$ in the Tg mice, already evident at 2 months of age, relative to the control animals.

by 20 months of age to about $60 \mu \mathrm{g} / \mathrm{g}$ of cortex (Fig. 3B). The average value for the non-Tg waterinsoluble $A \beta 42$ at 20 months of age was about 24-fold lower (2.5 $\mu \mathrm{g} / \mathrm{g}$ of cortex) than in the APP23 $\mathrm{Tg}$ mice and considered to be the basal endogenous value (Fig. 3B).

When the levels of total soluble and insoluble $\mathrm{A} \beta 40$, as measured by europium immunoassay in the APP23 Tg mice at 20 months of age, were added and averaged, they amounted to $700 \mu \mathrm{g} / \mathrm{g}$ of brain. By the same age, the water-soluble and -insoluble A $\beta 42$ yielded a mean value of $91.5 \mu \mathrm{g} / \mathrm{g}$ of brain (Figs. 2 and 3). There was a 7.7-fold greater abundance of $\mathrm{A} \beta 40$ over $\mathrm{A} \beta 42$. The $\mathrm{A} \beta 40: \mathrm{A} \beta 42$ ratio yielded by the acid extraction and subsequent chromatographic separation on a high performance liquid chromatography reverse-phase 5RPC column, in a previous study, however, showed only a 3 - to 4 -fold greater abundance of $\mathrm{A} \beta 40$ over $\mathrm{A} \beta 42$ (13). The discrepancy may be due to the use of 22-month-old $\mathrm{Tg}$ mice in the previous study rather than the younger 20-month-old $\mathrm{Tg}$ mice in the present study. Furthermore, during the water extraction for the EuIA some of the water-soluble $A \beta 42$ may be bound
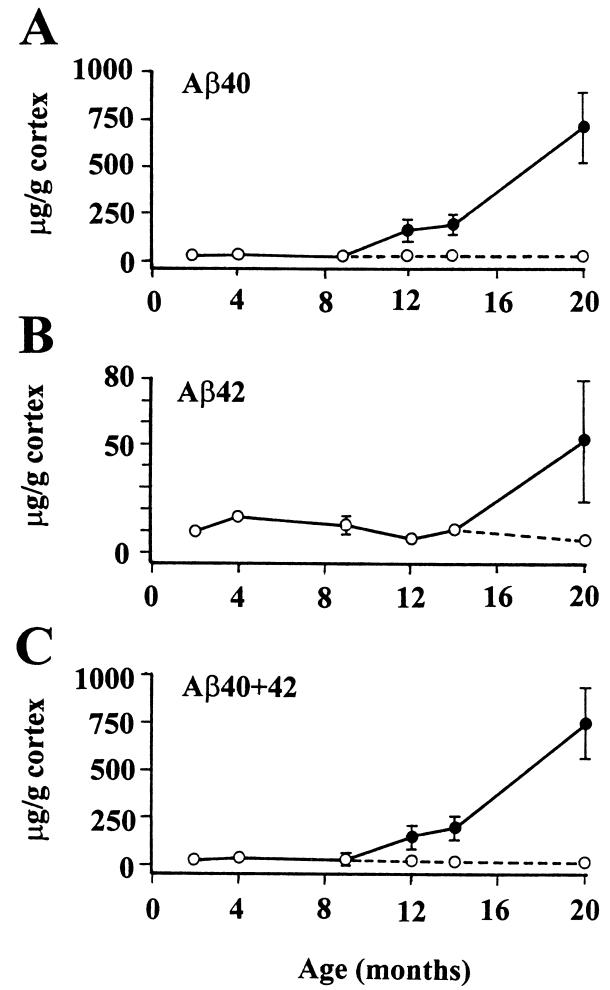

Fig. 3. The amounts of water-insoluble (SDS-GDFA soluble) $A \beta$ in the APP23 Tg mice and non-Tg littermate brains. The quantification was done by EuIA. The mice ages are as in Figure 1. Solid lines, $\mathrm{Tg}$ mice; broken lines, control mice. (A) $\mathrm{A} \beta 40$. (B) $\mathrm{A} \beta 42$. (C) The Sum of both $\mathrm{A} \beta$ peptides. The water-insoluble $A \beta 40$ begins to increase at 9 months of age, reaching a substantial level by 20 months of age in the Tg mice. The increase of the $A \beta 42$ is less pronounced than the $A \beta 40$ in the Tg mice. The EuIA demonstrated a ratio of $A \beta 40$ to $A \beta 42$ of 8.5:1.0.

to other molecules which hinders immunoreactive epitopes (22).

\section{Levels of ApoE in $\mathrm{Tg}$ Mouse Brains}

The values of ApoE in the brains of the APP23 Tg mice were elevated relative to those obtained for the non-Tg littermates (Fig. 4). This elevation was already noticeable at 2 months of age and became significant $(p=0.020)$ in the Tg mice at 14 and 20 months of age (Fig. 4).

\section{Histologic Evolution of Amyloid Deposits}

In the present study, deposits of $\mathrm{A} \beta$ are first detected by histology in the brain at 9 months of age in the APP23 Tg mice. However, in a more extensive study, amyloid deposits have been observed in animals as young as 6.7 months of age (M. Staufenbiel, unpublished observations). Such deposits are isolated or widely scattered and reside mainly in the frontal cortex (Fig. 5A). With increasing age, plaques increase in number and in size, ranging up to $100 \mu \mathrm{m}$ in diameter at 12 months (Fig. 5B), $180 \mu \mathrm{m}$ at 14 months (Fig. 5C), and $200 \mu \mathrm{m}$ at 20 months (Fig. 5D). 


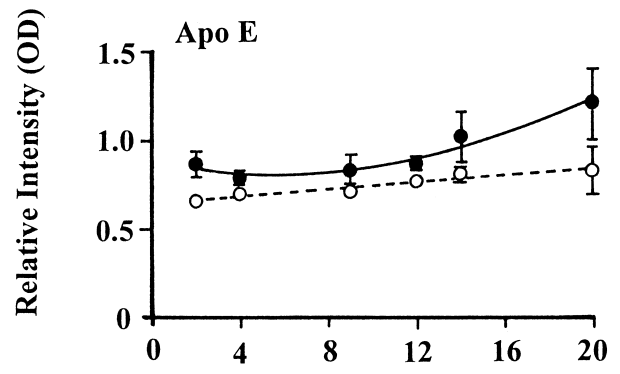

Age (months)

Fig. 4. The age-dependent relative levels of ApoE in the cerebral cortex of the APP23 Tg mice and control littermates measured by Western blot scanning densitometry. Solid line, Tg mice; broken line, control mice.

Amyloid plaque core morphology also changes with age. At 9 months, plaques consist mostly of small dense bodies about $10-20 \mu \mathrm{m}$ in diameter (Fig. 5E). Beginning at 12 months, star-like forms are more common, with the arms of the stars composed of radially arranged bundles of filaments (Fig. 5FG). Cerebral amyloid angiopathy is first apparent at 9 months of age in APP2 $3 \mathrm{Tg}$ mice and, like the A $\beta$ plaques, becomes increasingly more common in older animals. The thickness of the vascular amyloid coat also increases in older animals (Fig. 5D), with some vessels in 14- and 20-month-old animals exhibiting prominent nodular deposits of amyloid (Fig. 5H).

Staining patterns for $\mathrm{A} \beta$ immunocytochemistry vary in the 14- and 20-month-old APP23 Tg mouse brains, depending on the antibody used. With the 6E10 antibody (Fig. 5I), plaque cores are intensely stained and diffuse plaque-like staining is also present, whereas the R163 antibody, against $A \beta 40$, stains plaque cores intensely (Fig. 5J). The R165 antibody, against $\mathrm{A} \beta 42$, stained fewer plaque cores with less intensity (Fig. 5K), but also resulted in faint, focal staining of the neuropil, similar to diffuse plaques seen in the human brains. Sections stained with the antibody against ApoE showed intense staining of plaques (Fig. 5L) from their first appearance at 9 months of age. Control sections for the ApoE antibody showed no staining when the primary antibody was omitted.

Immunocytochemistry for $\mathrm{A} \beta$ and $\beta \mathrm{APP}$ revealed cytoplasmic staining of neurons. The $6 \mathrm{E} 10$ antibody against $\mathrm{A} \beta$ showed intense, punctate staining within the cytoplasm of cortical (mostly layer III, Fig. 5M) and hippocampal (CAl region) pyramidal neurons (data not shown). This was first apparent in 4-month-old animals when only a few neurons per section were positive. Both the number of positive neurons and the number and intensity of intracellular punctae increased progressively with age so that by 20 months positively stained neurons were very common in the cortex. Such intracellular staining was not present, however, with either the

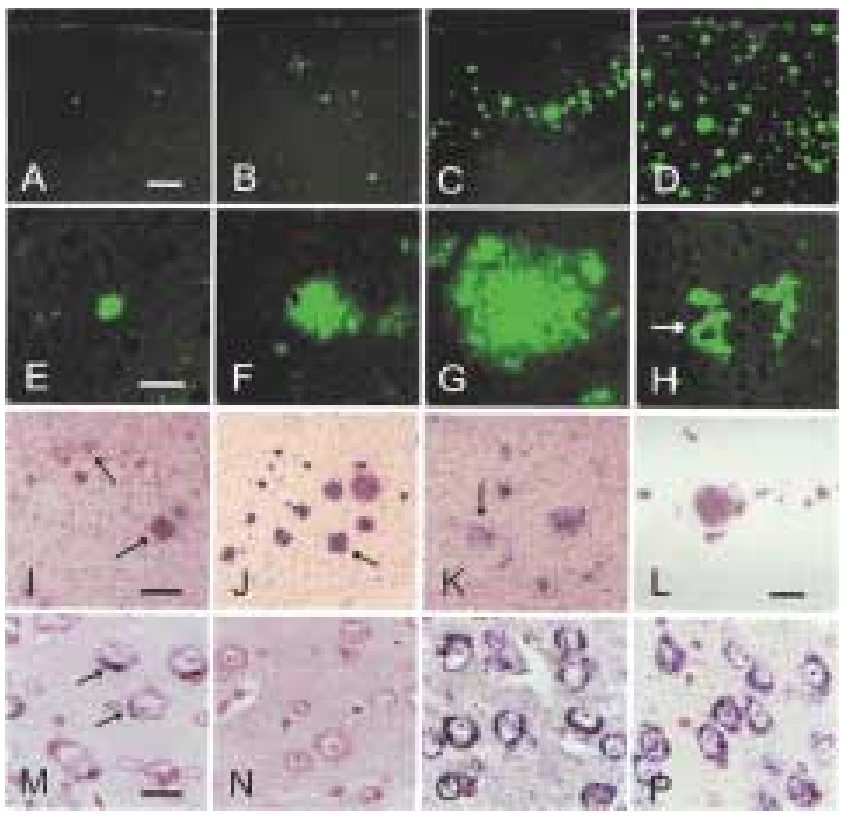

Fig. 5. Photomicrographs of sections from APP23 Tg mice brains. Images $\mathbf{A}$ through $\mathbf{H}$ were stained with thioflavine $\mathrm{S}$ and photographed using scanning laser confocal microscopy. Images A through D illustrate the progressive accumulation of cortical plaques with increasing age of the Tg animal, representing mice aged 9, 12, 14, and 20 months, respectively. Calibration bar in A equals $500 \mu \mathrm{m}$ and serves for A-D. Images E through $\mathbf{G}$ depict the typical increase in plaque size with increasing age. Nine-, 12-, and 20-month-old animals are represented in $\mathbf{E}, \mathbf{F}$, and $\mathbf{G}$, respectively. Image $\mathbf{H}$ shows two blood vessels with intense thioflavine fluorescence of their walls as well as exophytic growths of amyloid extending from the vessel wall into the adjacent neuropil (arrow). Calibration bar in E equals $50 \mu \mathrm{m}$ and serves for E-H. Photomicrographs I through $\mathbf{L}$ show immunohistochemical staining of cortical plaques with antibodies to $\mathrm{A} \beta(\mathbf{I}-\mathbf{K})$ and $\operatorname{ApoE}(\mathbf{L})$. Sections I-K were counterstained with neutral red. Antibody 6E10, against $\mathrm{A} \beta 1-17$, stains both amyloid cores (I, lower arrow) and diffuse-type plaques (I, upper arrow). The end-specific antibody against $\mathrm{A} \beta \mathrm{N}-40, \mathrm{R} 163$, stains cores intensely (J, arrow), but does not stain diffuse plaques. The end-specific antibody directed at $\mathrm{A} \beta \mathrm{N}-42, \mathrm{R} 165$, stains diffuse plaques (K, arrow), but cores are stained poorly. Calibration bar in I equals $100 \mathrm{~mm}$ and serves for I-K. Staining for ApoE revealed plaques in numbers and morphology similar to that seen with thioflavine S staining (L); calibration bar equals $75 \mu \mathrm{m}$. Photomicrographs $\mathbf{M}$ through $\mathbf{P}$ are included to show intracellular findings with $\mathrm{A} \beta$ and APP antibodies. The sections were counterstained for cellular detail with neutral red. Antibody 6E10 reveals intracytoplasmic granules within large cortical pyramidal neurons (M, arrows). Sections stained with the end-specific antibodies $\mathrm{R} 163$ and R165, against carboxy terminal residues of $\mathrm{A} \beta 40$ and $\mathrm{A} \beta 42$, respectively, did not show any intracellular reaction product (staining with R165 is shown in N; staining with R163 was similar but is not shown). The sections seen in $\mathbf{O}$ and $P$ were stained with the $22 \mathrm{C} 11$ and R37 antibodies for the $\mathrm{N}$ - and C-termini of APP, respectively. Note the presence of abundant intraneuronal granular reaction product. The calibration bar in $\mathbf{M}$ equals $15 \mathrm{~mm}$ and serves for $\mathbf{M}-\mathbf{P}$.

R163 (Fig. 5N) or R165 antibodies (data not shown) against $\mathrm{A} \beta$ ending at amino acid 40 or 42 , respectively. Staining with the antibodies 22C11 (Fig. 5O) and R37 (Fig. 5P) against the $\mathrm{N}$ - and C-terminal 
portions of APP, respectively, showed frequent and profuse intraneuronal granular deposits within the majority of cortical neurons.

None of the control sections were stained when antibodies directed at $\mathrm{A} \beta$ were used. This included sections of brain from APP23 Tg mice stained as indicated, but with omission of the primary antibody, as well as sections from control, non-Tg littermates. For APP immunocytochemistry, non-Tg littermates showed light neuropil staining but lacked intraneuronal staining. Control sections of brain prepared by omitting the primary antibody were devoid of staining in $\mathrm{Tg}$ and non-Tg mouse brain.

\section{Vascular Amyloid Load}

Whole-mount preparations of the vascular tree from 22-month-old APP23 Tg mouse cerebrum, stained with thioflavine $S$, revealed an extensive and heavy load of amyloid in the walls of arteries and arterioles in the brain parenchyma and in the leptomeninges (Fig. 6B). Notably, this contrasted sharply with the light and scanty load of vascular amyloid observed in another strain of $\mathrm{Tg}$ rodent, the Tg2675 mice, also at 22 months of age (Fig. 6A).

\section{Discussion}

We demonstrated that $\mathrm{A} \beta 40$ and $\mathrm{A} \beta 42$ levels in the plasma of APP23 Tg mice were not significantly elevated above those of non-Tg mice at any point between 2 and 20 months of age. In contrast, watersoluble and water-insoluble $\mathrm{A} \beta$ in the brain were elevated at 2 and 9 months, respectively, and increased considerably with advancing age. The rise of $\mathrm{A} \beta$ in the brain was accompanied by a significant increase in ApoE, especially between 14 and 20 months of age. Histologic and immunocytochemical analyses revealed morphologic changes in the APP23 Tg mice that reflected the increased brain A $\beta$ levels. Amyloid plaques increased progressively in size and number from 9 to 20 months in the Tg mice, and a substantial amount of $\mathrm{A} \beta$ was deposited in vessel walls as cerebral amyloid angiopathy was histologically evident from the age of 9 months onward. Immunocytochemistry showed colocalization of ApoE, $\mathrm{A} \beta 40$, and $\mathrm{A} \beta 42$ in plaques, and also revealed APP within neuronal cytoplasm of the APP23 Tg mice.

The origin of $\mathrm{A} \beta$ in $\mathrm{AD}$ is uncertain, even though it is established that APP is the $\mathrm{A} \beta$ precursor molecule. Immunocytochemical analysis of APP23 Tg mice revealed APP localization to neuronal cell bodies. The possibility of $\mathrm{A} \beta$ in the neurons was also raised as they were stained with the $6 \mathrm{E} 10$ antibody, which initially suggests the presence of intraneuronal $\mathrm{A} \beta$. However, the lack of immunoreactivity with the R163 and R165 antibodies, which specifically recognize the $\mathrm{A} \beta$ peptide $\mathrm{C}$-termini, revealed that the $6 \mathrm{E} 10$ antibody is actually recognizing the $\mathrm{A} \beta$ sequence within the APP. The abundant intraneuronal staining
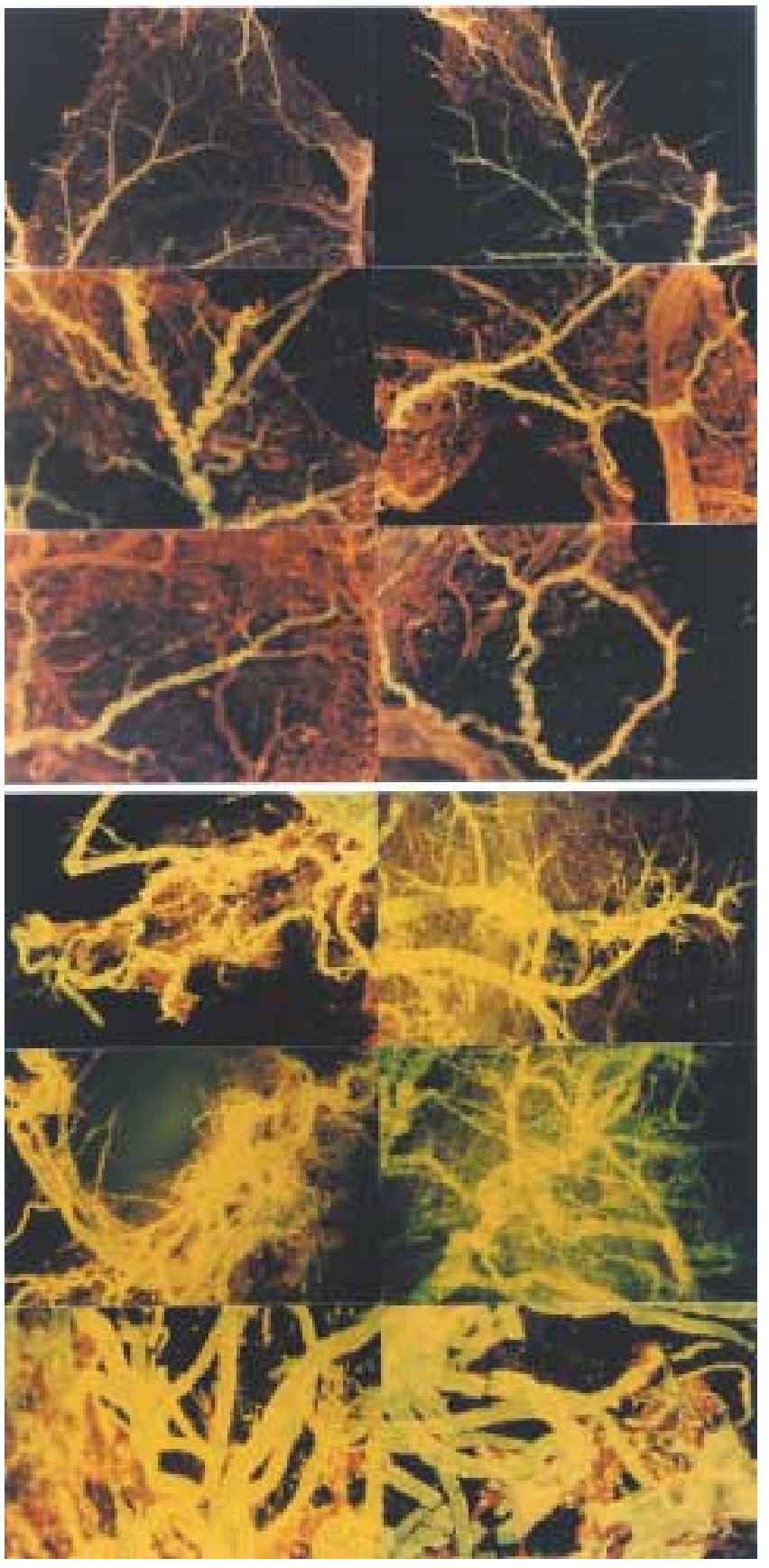

Fig. 6. Whole-mount preparations of Tg mice parenchymal vessels stained with thioflavine $S$ (yellow fluorescence). Top panel shows the Tg2576 mouse. Bottom panel corresponds to the APP23 $\mathrm{Tg}$ mouse. There is an overwhelming amount of vascular amyloid in the APP23 Tg mouse when compared to the Tg2576 mouse. The walls of most of the vessels are loaded with amyloid deposited along the perpendicularly oriented smooth muscle cells.

with antibodies against the $\mathrm{N}$ - and $\mathrm{C}$-termini of the APP molecule confirmed the presence of large amounts of full-length APP within these cells as early as 4 months of age. Therefore, it appears that intracellular $\mathrm{A} \beta$ concentrations remain at low, histochemically 
undetectable levels in these animals despite marked overexpression of mutant APP. This finding may have negative implications for recently emerging hypotheses regarding the importance of intraneuronal $\mathrm{A} \beta$ in $\mathrm{AD}$ pathogenesis $(22,23)$. Our immunocytochemical studies have shown that a large part of the neuronal cytoplasm is packed with APP that could cause severe neuronal damage at the extreme level expressed in the Tg mice. This may, per se, create an abnormal condition, which may not be part of the typical human AD pathogenesis.

Our experiments revealed that substantial differences exist in $\mathrm{A} \beta$ accumulation kinetics and patterns in different $\mathrm{Tg}$ mice strains that overproduce human amyloid through enhanced expression of APP. The amount of $\mathrm{A} \beta$ in the brain and plasma of the Tg2576 mice and control littermates was measured at intervals between 2-20 months (15). The levels of total $\mathrm{A} \beta$ in plasma increased up to 12 months of age in the $\mathrm{Tg} 2576$ mice, relative to controls, and then fell to almost endogenous $\mathrm{A} \beta$ levels (Fig. 7). In contrast, while both water-soluble and waterinsoluble forms of $\mathrm{A} \beta$ remained at basal levels in the brain until 9 months of age, $\mathrm{A} \beta$ increased exponentially from 12-20 months of age Amyloid deposits in the brain parenchyma are first discernible at 12 months of age in Tg2576 mice.

The dramatic differences between the APP23 and Tg2576 mice in the distribution of amyloid may be due in part to the cDNA construct used. The APP23 Tg mouse contains the $\mathrm{APP}_{751}$ cDNA construct and includes the Kunitz protease inhibitor domain, which is absent in the APP ${ }_{695}$ CDNA construct used in the $\mathrm{Tg} 2576 \mathrm{Tg}$ mice. Although both the $\mathrm{Tg}$ mouse APPs carry the Swedish mutations to enhance the generation of $\mathrm{A} \beta$, the promoters are different, with the Thy-1 in the APP23 Tg mouse and the hamster prion in the $\mathrm{Tg} 2576 \mathrm{Tg}$ mouse. At least as surprising as the difference between the two $\mathrm{Tg}$ mice is the difference between the control strains. This may be due to the different backgrounds of the

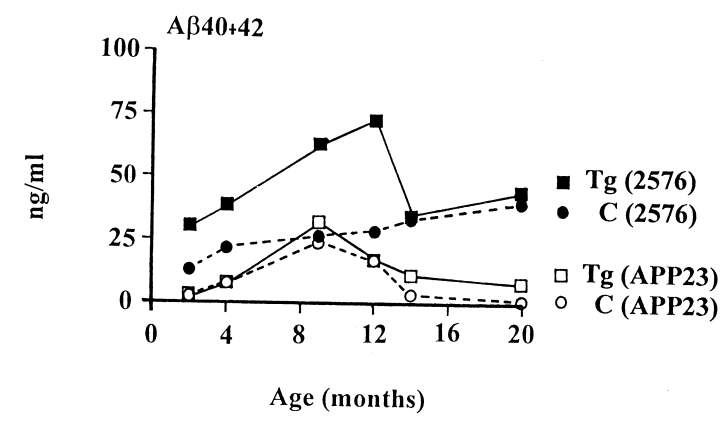

Fig. 7. Time-dependent comparison between the amount of plasma levels of total $A \beta$ between two strains of $\mathrm{Tg}$ mice (APP23 versus Tg2576) and their respective control littermates. $\mathrm{Tg}$, transgenic; C, non-transgenic controls. All measurements were carried out by EuIA and adjusted to $\mathrm{ng} / \mathrm{ml}$ of plasma. two Tg mice. The APP23 Tg mice are in the C57BL/6J (Black 6), which have been successfully back-crossed with the same strain of mice, while the Tg2576 mice were in the C57B6/SJL, which have been backcrossed to the wild-type B6SJL mice from Jackson Laboratories, Bar Harbor, Maine, USA.

The acute overexpression of proteins in transgenic mice may result in induction of compensatory physiologic responses designed to eliminate the abundant alien protein. Several mechanisms, alone or in concert, include extracellular proteolysis, microglial, and/or astroglial phagocytosis with lysosomal degradation, sequestration of $\mathrm{A} \beta$ by binding species such as ApoE or $\beta 2$-macroglobulin, followed by receptor-mediated endocytosis by brain or vascular cells expressing LDL or LRP receptors. Moreover, a portion of the $A \beta$ could be eliminated through the arachnoid granulations that remove cerebrospinal fluid (CSF) into the venous circulation.

In addition to direct mechanisms of $\mathrm{A} \beta$ elimination, levels of brain protein may be controlled by allowing transport into the blood. There are several situations in which molecules are constantly produced within brain tissue but the absence of disposal mechanisms leads to excessive accumulation either within cells or extracellular spaces. Thus, different amyloid polypeptides, like $\mathrm{A} \beta$, cystatin, ABri, and prions accumulate in the extracellular spaces of the cerebral cortex. The pattern of $\mathrm{A} \beta$ accumulation in the walls of intracerebral and leptomeningeal arteries in CAA suggests that it is deposited in the periarterial interstitial fluid drainage channels through which, as suggested, $\mathrm{A} \beta$ is normally eliminated from the human brain $(12,24)$. In CAA, $A \beta$ accumulates in the walls of cortical capillaries, arterioles, and small arteries and in leptomeningeal arteries to such a degree that it is stained in histologic preparations. Biochemical studies, however, have detected the presence of $A \beta$ in the walls of arteries as large as the middle cerebral artery and basilar artery in young adults in their third decade. Levels of $A \beta$ in these arteries are significantly increased in $\mathrm{AD}$, but no $\mathrm{A} \beta$ accumulation has been detected in extracranial arteries (25). These observations support the hypothesis that soluble $\mathrm{A} \beta$, possibly bound to ApoE, is eliminated from the human brain along periarterial interstitial fluid drainage pathways (26) that are homologous with those described in rodents $(5,6,27)$. Soluble and particulate tracers injected into the central gray matter of the rodent brain pass along periarterial pathways into regional lymph nodes in the neck $(6,28,29)$. Experimental studies strongly suggest that these pathways play a significant role in B-cell immunity and T-cell immune reactions in the rodent brain $(6,28-30)$.

The pattern of $\mathrm{A} \beta$ abundance in the $\operatorname{Tg} 2576$ mice is in marked contrast to that in the APP23 Tg mice. High levels of water-soluble $\mathrm{A} \beta$ in the brains of APP23 Tg mice from 2-20 months of age imply that clearance of $\mathrm{A} \beta$ may not be as efficient as in Tg2576 
mice below 12 months of age. This argument is supported by the low values of $A \beta$ found in the plasma of the APP23 $\mathrm{Tg}$ mice relative to those observed in the Tg2576 mice (Fig. 7). The less efficient clearance of $\mathrm{A} \beta$ is reflected in the earlier histologic detection of amyloid in the brains of the APP23 Tg mice at 7-9 months compared to the Tg2576 mice at approximately 10-12 months. The vascular amyloid deposition pattern characteristic of APP23 Tg mice and $\mathrm{AD}$, in which an inverse gradient is evident, initiating in the arterioles and small arteries with decreased deposition detectable in larger diameter vessels is consistent with a failure to clear the high levels of soluble amyloid into circulation. In AD, the deposition of vascular amyloid starts at the most peripheral layer of the tunica media, which is in direct contact with periarterial spaces, suggesting that the soluble $\mathrm{A} \beta$ is entrapped by the extracellular matrix as it moves into systemic circulation. Such severe changes in the integrity of the cerebral vessels, with a loss of vascular myocytes, results in compromised cerebral blood flow and ischemia. The vast amount of vascular amyloid in the APP23 Tg mice results in a prominent pathology leading to infarcts, hemorrhagic strokes, aneurisms, hematomas, vascular obstructions, and vasculitis $(31,32)$. These pathologic changes have not been described for the Tg2576 mice in which the amount of vascular amyloid in comparison is moderate.

APP23 Tg mice resemble AD patients who carry the ApoE4/E4 phenotype, which results in an earlier onset of $A D$ with a preponderance of $A \beta 40$ in the brain and an overwhelming parenchymal and leptomeningeal CAA. In contrast, the suggested efficient $\mathrm{A} \beta$ elimination from the brain to the blood during early life of the Tg2576 mice may be analogous to human AD patients with phenotypes E3/E3 or E3/E2 in which there is a lesser amount of CAA. If the ApoE phenotype plays an important role in determining the load of vascular $A \beta$, then potential differences in the ApoE primary structure between the strains of $\mathrm{Tg}$ mice may give further clues as to how ApoE is involved in $\mathrm{A} \beta$ transport and elimination.

Although CAA occurs in both the APP23 Tg mice and Tg2576 mice, it is only histologically discernible after $\mathrm{A} \beta 40$ and $\mathrm{A} \beta 42$ have accumulated in the brain and drainage of $\mathrm{A} \beta$ to the blood has apparently ceased in the $\operatorname{Tg} 2576$ mice. As in human cerebral vessels, biochemically detectable amyloid (33) may be deposited prior to its appearance as histologically detectable CAA. A measurable amount of $\mathrm{A} \beta$, estimated at about $20 \mathrm{ng} / \mathrm{mg}$ of protein, is needed for the visual detection of amyloid by histologic techniques (K. Bales, personal communication). Insoluble A $\beta 42$ may impede the drainage of the more soluble $\mathrm{A} \beta 40$ and provide the initial template for soluble A $\beta 40$ polymerization into fibrils. This appears to be the case in human $\mathrm{AD}$ in which $\mathrm{A} \beta 42$ accumulates in vessel walls in CAA before the more soluble $A \beta 40$, but thereafter $A \beta 40$ levels rise both within the brain and in vessel walls. The incomplete separation of interstitial fluid drainage pathways from the CSF compartment in rodents $(5,27)$ is reflected in the very high levels of $\mathrm{A} \beta$ amounting to approximately $40 \mathrm{ng} / \mathrm{ml}$ in the APP23 Tg mice CSF (31). These levels are well above those seen in human AD CSF. Furthermore, CSF $\mathrm{A} \beta 42$ and $\mathrm{A} \beta 40$ levels are decreased in patients with $\mathrm{AD}$ relative to nondemented controls. This probably reflects the greater separation of Interstitial Fluid (ISF) drainage from the CSF in the human brain compared with rodents (6). In humans, the CSF and periarterial space are segregated by the pia mater, whereas in rodents, the separation between these compartments is more primitive and the periarterial space directly communicates with the CSF subarachnoidal space. This may be an additional factor in the higher incidence of $\mathrm{A} \beta$ accumulation in aged humans compared to aged animals.

The heterogeneity exhibited in almost every aspect of AD patients has complicated attempts to define risk factors and predict the course of the disease. Consideration of the incomplete analogy between $\mathrm{AD}$ and the Tg mouse models has led others to conclude that the more exact $\mathrm{AD}$ modeling may require the "humanizing" of Tg systems (34). However, Tg mice may be used to investigate separate facets of $\mathrm{AD}$, even if these models fail to completely mimic the entire AD complex. We have confirmed that the APP23 and the Tg2576 Tg mice can be used to investigate the critical elimination of $\mathrm{A} \beta$ from the brain. These transgenic model systems clearly will enable productive evaluations of novel therapeutic interventions directed toward decreasing amyloid formation and deposition.

\section{Acknowledgments}

This study was partially supported by The State of Arizona Alzheimer's Disease Research Center and by the National Institutes of Health (AG-17490).

\section{References}

1. Lue LF, Kuo YM, Roher AE, et al. (1999). Soluble amyloid beta peptide concentration as a predictor of synaptic change in Alzheimer's disease. Am. J. Path. 155: 853-862.

2. McLean CA, Cherny RA, Fraser FW, et al. (1999). Soluble pool of Abeta amyloid as a determinant of severity of neurodegeneration in Alzheimer's disease. Ann. Neurol. 46: 860866.

3. Nicholson C, Sykova E. (1998). Extracellular space structure revealed by diffusion analysis. Trends Neurosci. 21: 207-215.

4. Cserr HF, Harling BC, Ichimura T, Knopf PM, Yamada S. (1990). Drainage of cerebral extracellular fluids into cervical lymph: An afferent limb in brain/immune system interactions. Fernstrom Foundation Series 14: 413-420.

5. Zhang ET, Richards HK, Kida S, Weller RO. (1992). Directional and compartmentalised drainage of interstitial fluid and cerebrospinal fluid from the rat brain. Acta Neuropathogica 83: 233-239.

6. Weller RO. (1998). Pathology of cerebrospinal fluid and interstitial fluid of the CNS: significance for Alzheimer disease, prion disorders and multiple sclerosis. J. Neuropathol. Exp. Neurol. 57: 885-894. 
7. Vinters HV, Wang ZZ, Secor DL. (1996). Brain parenchymal and microvascular amyloid in Alzheimer's disease. Brain Pathol. 6: 179-195.

8. Olafsson I, Thorsteinsson L, Jensson O. (1996). The molecular pathology of hereditary cystatin $C$ amyloid angiopathy causing brain hemorrhage. Brain Pathol. 6: 121-126.

9. Ghetti B, Piccardo P, Frangione B, et al. (1996). Prion protein hereditary amyloidosis: Parenchymal and vascular. Semin. Virol. 7: 189-200.

10. Revesz T, Holton JL, Doshi B, Anderton BH, Scaravilli F, Plant GT. (1999). Cytoskeletal pathology in familial cerebral amyloid angiopathy (British type) with non-neuritic amyloid plaque formation. Acta Neuropathol. 97: 170-176.

11. Mead S, James-Galton M, Revesz T, et al. (2000). Familial British dementia with amyloid angiopathy: early clinical, neuropsychological and imaging findings. Brain 123: 975991.

12. Weller RO, Massey A, Newman TA, Hutchings M, Kuo YM, Roher AE. (1998). Cerebral amyloid angiopathy: amyloid beta accumulates in putative interstitial fluid drainage pathways in Alzheimer's disease. Am. J. Pathol. 153: 725-733.

13. Kuo YM, Kokjohn TA, Beach TG, et al. (2001). Comparative analysis of $\mathrm{A} \beta$ chemical structure and amyloid plaque morphology of APP23 transgenic mice. J. Biol. Chem. 276: 1299112998.

14. Roses AD. (1996). Apolipoprotein E alleles as risk factors in Alzheimer's disease. Annu. Rev. Med. 47: 387-400.

15. Kuo YM, Crawford F, Mullan M, et al. (2000). Elevated A $\beta$ and apolipoprotein $\mathrm{E}$ in $\mathrm{A} \beta \mathrm{PP}$ transgenic mice and its relationship to amyloid accumulation in Alzheimer's disease. Mol. Med. 6: 430-439.

16. Holmquist L, Carlson K. (1977). Selective extraction of human serum very low density apolipoproteins with organic solvents. Biochem. Biophys. Acta 493: 400-409.

17. Dolphin PJ. (1980). Organic extraction and preparative isolectric focusing of rat serum apolipoproteins. FEBS Lett. 117: 252258.

18. Dolphin PJ, Wong L, Rubinstein D. (1978). A comparison of some immunological characteristics of very low density lipoproteins of normal and hypercholesterolemic rat sera. Can. J. Biochem. 56: 673-683.

19. Beach TG, Tago H, Nagai T, Kimura H, McGeer PL, McGeer EG. (1987). Perfusion-fixation of the human brain for immunohistochemistry: comparison with immersion-fixation. $J$. Neurosci. Meth. 19: 183-192.

20. Mehta PD, Dalton AJ, Mehta SP, Kim KS, Sersen EA, Wisniewski HM. (1998). Increased plasma amyloid A $\beta$ protein 1-42 levels in Down syndrome. Neurosci. Lett. 241: 13-16.
21. Ishii T, Kametani F, Haga S, Sato M. (1989). The immunohistochemical demonstration of subsequences of the precursor of the amyloid A4 protein in senile plaques in Alzheimer's disease. Neuropathol. Appl. Neurobiol. 15: 135-147.

22. Gouras GK, Tsai J, Naslund J, et al. (2000). Intraneuronal A $\beta$ 42 accumulation in human brain. Am. J. Pathol. 156: 15-20.

23. Wilson CA, Doms RW, Lee VMY. (1999). Intracellular APP processing and $\mathrm{A} \beta$ production in Alzheimer's disease. $\mathrm{J}$. Neuropathol. Exp. Neurol. 58: 787-794.

24. Weller RO, Massey A, Kuo YM, Roher AE. (2000). Cerebral amyloid angiopathy: accumulation of A beta in interstitial fluid drainage pathways in Alzheimer's disease. Ann. NY Acad. Sci. 903: 110-117.

25. Shinkai Y, Yoshimura M, Ito Y, et al. (1995). Amyloid betaproteins $1-40$ and $1-42(43)$ in the soluble fraction of extraand intracranial blood vessels. Ann. Neurol. 38: 421-428.

26. Zhang ET, Inman CBE, Weller RO. (1990). Interrelationships of the pia mater and the perivascular (Virchow-Robin) spaces in the human cerebrum. J. Anat. 170: 111-123.

27. Kida S, Pantazis A, Weller RO. (1993). CSF drains directly from the subarachnoid space into nasal lymphatics in the rat. Anatomy, histology and immunological significance. $\mathrm{Neu}$ ropathol. Appl. Neurobiol. 19: 480-488.

28. Knopf PM, Cserr HF, Nolan SC, Wu TY, Harling-Berg CJ. (1995). Physiology and immunology of lymphatic drainage of interstitial and cerebrospinal fluid from the brain. $\mathrm{Neu}$ ropathol. Appl. Neurobiol. 21 : 175-180.

29. Cserr HF, DePasquale M, Harling-Berg CJ, Park JT, Knopf PM. (1992). Afferent and efferent arms of the humoral immune response to CSF-administered albumins in a rat model with normal blood-brain barrier permeability. J. Neuroimmunology 41: 195-202.

30. Phillips MJ, Needham M, Weller RO. (1997). Role of cervical lymph nodes in autoimmune encephalomyelitis in the Lewis rat. J. Pathol. 182: 457-464.

31. Calhoun ME, Burgermeister P, Phinney AL, et al. (1999). Neuronal overexpression of mutant amyloid precursor protein results in prominent deposition of cerebrovascular amyloid. Proc. Nat. Acad. Sci. U.S.A. 96: 14088-14093.

32. Winkler DT, Bondolfi L, Herzig MC, et al. (2001). Spontaneous hemorrhagic stroke in a mouse model of cerebral amyloid angiopathy. J. Neurosci. 21: 1619-1627.

33. Shinkai Y, Yoshimura M, Morishima-Kawashima M, et al. (1997). Amyloid beta-protein deposition in the leptomeninges and cerebral cortex. Ann. Neurol. 42: 899-908.

34. Guenette SY, Tanzi RE. (1999). Progress toward valid transgenic mouse models for Alzheimer's disease. Neurobiol. Aging 20: 201-211. 